\title{
ADMINISTRATIVE OBJECTION IN CUSTOMS CODE
}

Aylin ARMAĞAN ${ }^{1}$
Serkan SEYHAN ${ }^{2}$

\begin{abstract}
In Article 242 of the Customs Code under the section "Objection", objections against the administrative decisions customs tax and penalties and the administrative decisions are regulated. This administrative appeal contained in the Customs Law Act is generally accepted as a mandatory administrative objection in the case-law of the higher courts, in the administrative practice and in academic studies on this subject. When the secondary legislation on the said provision is examined, it is understood that this practice contradicts both the basic principles of administrative jurisdiction and the fundamental human rights. Thus this administrative application affects the taxpayer's right to access to court directly. Property right of the taxpayer is also affected inderectly because of the interest of default the extended administrative and legal process may cause.

As a result of this study, the conclusion that the existing provision has been misjudged by the administrative and judicial bodies. It is accepted as a mandatory way yet the regulation in the Customs Code clearly shows a discretionary application path. Subsequently, the reference to Article 10 of the Administrative Procedure Code as the source of the regulations in the secondary legislation relating to the provision is wrong in our opinion. Because in act 10 of this code, is an provison for situations where administrative bodies does not establish a procedure. However, this administrative objection contained in the Customs Code only can be made against an administrative action by the customs administration. In the light of these findings, it is emphasized that the fundamental rights of individuals may be violated. Because the prolongation of the administrative objection, the right to access to the court of the taxpayers is violated.
\end{abstract}

Keywords: Customs Tax Law, Administrative Objection, Administrative Application

JEL Code: K23, K34.

\section{Introduction}

In Article 242 of the Customs Code, the administrative objections against customs tax and penalties andadministrative decisions are regulated. This regulation is considered to be a mandatory administrative objection, which must be completed before opening a lawsuit in both the doctrine and the high judicial decisions. For this reason, the administrative appeal process envisaged by the Customs Code has a direct impact on the rights of individuals. The failure to file an administrative appeal shall also prevent the prosecution. For this reason, it is important to clarify the procedure to administrative appeal. In this context, the scope of the study is toclarify administrative objection institution which is regulated under Article 242 of the Customs Code and secondary legislation, particularly the Customs Regulation.

Within the scope of this study, the legal framework of the regulation in the Customs Law will be tried to be drawn, not only the provision, but also the secondary legislation concerning the provision. Next, the elements of this administrative remedy and the problems it creates in the legal order will be discussed. These are respectively; the element of necessity, the implementation of the additional period that the administration may take at the point of responding to the

${ }_{1}^{1}$ Res. Asst., Alttnbaş University, Faculty of Law, Division of Fiscal Law, aylin.armagan@altinbas.edu.tr

2 Res. Asst., ìstanbul Kültür University, Faculty of Law, Division of Administrative Law, s.seyhan@iku.edu.tr 
applications and the attributions to other regulations. Finally, these regulations will be examined within the framework of fundamental rights and freedoms.

\section{Legal Framework of Administrative Objection in Customs Law}

The administrative objection in the Customs Code is regulated by Article 242 of the Law. In accordance with paragraph 2 of the article, within 30 days following the administrative objection, the customs directorate must respond to the objection. However, according to Article 586 of Customs Regulations in cases where no decision can be taken within thirty days, the second paragraph of Article 6 of the Code shall apply. According to the Article 6/2 of the Customs Code, if it is not possible for the customs administration to comply with the period set forth in the law, it is arranged that the contracting authority should inform the applicant of the rightful reason for the exceeding the period and the additional period they deem necessary.

In the circular published in 2014 on the issue of responding to the administrative appeal by the General Directorate of Customs, the issue of determining this additional period is regulated. In the said Circular, the provision on which the additional period shall be based is shown as Art. 10 of the Procedure of Administrative Justice Act (PAJA). Again, according to the Circular and Art. 10 of PAJA, this extended period shall be determined not to exceed 6 months from the date of application. On the other hand, even if the additional period was used, since the applicants could not obtain a definite result within 30 days, they can file a lawsuit according to the provision of $10 / 2$.

\section{Assessment of the Legal Structure}

\subsection{Assessment on Obligation Element}

Although Article $242 / 1$ of the Customs Code explicitly provides for an arbitrary objection, the opinion of the Council of State and the circulars issued by the Ministry of Customs and Trade provide the opinion that the said provision is an administrative remedy which must be exhausted (Koban \& Ercan, 2017: 24).

When the reason of the provision is examined, it can be seen that an explanation cannot be made in terms of the necessity of the administrative appeal. When interpreted as a verb clause, it is understood that a mode is used which refers to probability (Kağıtcıoğlu, 2017: 246). Considering the literal meaning of the provision, it should be accepted that the administrative objection path set out in Article 242 is arbitrary. In some of the decisions made by the local courts recently, the case law has also started to emerge that it is not mandatory (Sarıaslan, 2018: 361).

\subsection{Assessment on Extention}

When Article 242 of the Customs Code and secondary legislation examined, it is seen that when objection can not be replied within 30 days, additional time can be taken by the administration, this additional period can not exceed 6 months due to the regulation in PAJA Art.10. This understanding of the circular is open to discussion. Because the six-month period referred to in Article 10 is not a limitation for an additional period that the administration may receive at the point of response to the reply. The six-month period was set for the purpose of limiting the 
period during which individuals may take to wait the administrative authority's final decision. Other kind of understanding, will be contrary to the verbal interpretation of the provision which dictates as "waiting period can not exceed 6 months".

\subsection{Assessment on Atributions to Customs Code Art.6 and Code of Administrative Prosedure}

\section{Art. 10}

When the legal framework of the administrative objection path in the Customs Code is taken into consideration, in the case of determining the limits of the additional time provision ther is an atribution to Art. 6 of the Customs Code and another atribution to PAJAArt. 10 for the application procedure and in the period of the reply. PAJAArt. 10 regulates the applications or objections in the absence of any action previously established in the same subject. On the other hand, PAJAArt. 11 regulates administrative objections to an administrative act established on the relevant branch orto remove of the administrative procedure.

If there is an administrative procedure in the middle of the case, PAJAArt. 10 cannot be applied, in this case it is necessary to go to Art.11 (Sancar, 1990: 82). It is stated that if there is an obligatory objection procedure PAJAArt. 11 can not be implemented. However, it can be understood from the expression of Customs Code Art. 242 this objection is not a obligatory administrative appeal. Therefore, the additional time element is incorectly based on Customs Code Art. 6 because of the incorrect identification of the necessity of the administrative objection in question.

Another point to be discussed at this point is whether the customs tax and penalties subject to the administrative objection are a revocable administrative action. Because administrative procedures can only be subject to the case when they are absolute and executive (Candan, 2006: 71). The absolutity and executivity of the administrative procedure shall mean that the administrative unit and body which regulate the procedure, does not need consent or approval of another administrative units and other bodies of the state (Atay, 2012: 425; Erkut, 1990: 119). Customs procedures, however, are mostly those that are required by customs legislation in the customs administration and they should be accepted as one-sided and individual procedures of the administration (Sarlaslan, 2018: 348). When the customs taxes and penalties which are the subject of administrative objection mentioned in Art. 242, there is no doubt that these are the unilateral and individual procedures of the administration. Considering that the taxes and penalties imposed by the customs administration do not need to be submitted to the approval of another administrative authority for the acquisition of law in the legal order, these administrative procedures should be considered to be absolute andexecutive. Therefore, these procedures of the customs administration may be subject to litigation.

\subsection{Assessment on Fundamental Rights and Freedoms}

The mandatory administrative objection regulated by the Customs Code, must be understood clearly as it is linkedright to legal remedy since the necessity of exhaustion before the judicial system and the possibility of the loss of the right because of the complete closure of the judicial pathif the time is missed. This procedure is also linked to the right of property, which is one of the the most basic rights of the individuals, since the customs duties and penalties that constitute the subject of the administrative objection can effect individuals property. 
In the first part, wher the legal framework is tried to be drawn. As seen administrative objection is not regulated by a single law and the application of the provisions of the Customs Code, as well as the provisions of the PAJA, the Ministry of Customs and the Council of State and this prosedure shaped by the case law. It is contrary to the Constitution that the way of mandatory administrative appeal is regulated in law in a complicated way which may cause the individuals to lose their rights in a way mentioned in the reason of the provision of Art. 40/2 of the Constitution.

The administrative objection in the customs law should also be examined within the framework of the right to legal remedy. Because, the government draws an administrative procedure to be consumed before jurisdiction and creates a temporary obstacle in the stage of going to the judiciary. The European Convention on Human Rights does not explicitly regulate right to legal remedy. However, it is to be considered part of the ECHR under the right to a fair trial and the right to effective remedywhich are regulated by articles 6 and 13. In Article 36 of our Constitution, the right to legal remedy is guaranteed. This freedom is not only in the execution of the lawsuits filed but also in the freedom of individuals to go to the judiciary when there is not a case yet opened (Öztürk, 2015: 78).

The mandatory administrative appeal procedure limits the access of individuals to the court within the framework of freedom of rights. These restrictions are brought with the provisions regulating who can take legal action within each country's internal legislation (Aydın, 2013: 278). However, these limitations should not be touched on the essence of the right and should be arranged in a way that does not eliminate the purpose of existence (Kaşıkçı, 2017: 548). Parallel to this, it is said that the right of access to court by the Constitutional Court is not an absolute right, but it is violated if limitations regulated by the state determines absolute and strict time restirictions and these limitations are too complex and discouraging.

\section{Conclusion}

It is necessary to accept that the administrative objection path in Article 242 of the Customs Code is a discretionary administrative remedy, taking into account the nature of the literary meaning of the provision. When we look at Article 6 of the Customs Code with the guidance of Article 586 of the Customs Regulation, it is said that the period specified can be exceeded if it is not possible to comply with the period by the customs administration. There is no clarity as to how this additional period in this provision is determined and its limits.It is observed that this additional period was based on PAJAArt. 10by the circular of Ministry of Customs and Trade. On the other hand, PAJAArt.10 is a provision that regulates the applications that will be made to the administration for the purpose of establishing a procedure in the lack of any. When we look at the Customs Code, it is seen that there is already a customs tax or penalty established, and that taxpayers apply to the administration against this administrative process. For these reasons, the regulation mentioned in the Art. 10 is cannot be the root of administrative objection. As can be seen, there are many contradictions in terms of the elements of the administrative objection procedure in the Customs Code. The fact that these contradictory statements and practices are not eliminated by the legislator leads to the destruction of basic human rights such as taxpayers' right to legal remedy and the right to property. 


\section{References}

Atay, E. (2012). Idare Hukuku, Ankara, Turhan Kitapevi.

Aydın, B. (2013). "Türk İdari Yargı Düzeninde Mahkemeye Erişim Hakkı”, Türkiye Adalet Akademisi Dergisi, Ekim, S. 15, pp. 271-296.

Candan, T. (2006). Açıklamalı Idari Yargılama Usulü Kanunu, Ankara, Maliye ve Hukuk Yayınları.

Erkut, C. (1990). Iptaı Davasının Konusunu Oluşturma Bakımından Idari Işlemin Kimliği, Ankara, Danıştay Matbaası.

Kağıtcıoğlu, M. (2017). “idari İ̧̧lem Teorisi Çerçevesinde İdari Merci Tecavüzü Kavramının Değerlendirilmesi", Türkiye Adalet Akademisi Dergisi, S. 30, pp. 237-371.

Kaşıkçı, M. (2017). "Vergi Hukuku Özelinde Mahkemeye Erişim Hakkı Üzerine Bir İnceleme”, Istanbul Üniversitesi Hukuk Fakültesi Mecmuası, C. 75, S. 2, pp. 535-553.

Koban, E. \& Ercan, T. (2017). “4458 Sayılı Gümrük Kanunu Uygulamasında Yaşanan Güncel Sorunlar ve Çözüm Önerileri”, Vergi Sorunları Dergisi, S. 343, pp. 22-28.

Öztürk, B. (2015). Hak Arama Özgürlüğü Çerçevesinde Zorunlu Idari Itiraz, Ankara, Yetkin Yayınları.

Sancar, M. (1990). “idari Yargılama Usulü Kanunun 10 ve 11. Maddeleri Bağlamında İptal Davalarında Süre”, Amme Idaresi Dergisi, C. 23, S. 1, pp. 69-88.

Sarıaslan, O. (2018). “Gümrük Uyuşmazlıklarında İdari İşlemlerin Nitelendirilmesi Sorunu: Hak Arama Hürriyeti Kapsamında Mülkiyet Hakkının Özüne iliş̧kin Sakıncalar", Uyuşmazlık Mahkemesi Dergisi, S. 11, pp. 341-373. 